\title{
Preparasi Penumbuhan Lapisan Tipis a-Si:H dengan Metode HWC-VHF-PECVD pada Variasi Daya rf
}

\author{
Elang J.S* dan Satwiko S \\ Jurusan Fisika, Universitas Negeri Jakarta \\ Rawamangum Muka, Jakarta 13220 \\ T. Winata \\ Laboratorium PECVD Fismatel, \\ Departemen Fisika Institut Teknologi Bandung \\ Jl. Ganesa 10, Bandung 40132
}

\begin{abstract}
Intisari
Metode Hot Wire Cell Very High Frequency PECVD (Plasma Enhanced Chemical Vapor Deposition) adalah metode pengembangan dari PECVD konvensional dan merupakan metode gabungan antara VHF-PECVD dan HWC-PECVD. Pada metode ini diharapkan mendapatkan laju deposisi yang tinggi, konduktivitas yang tinggi serta kandungan hidrogen yang rendah. Lapisan tipis a-Si:H dideposisi dengan gas Silan $(\mathrm{SiH} 4) 10 \%$ dalam gas Hidrogen $\left(\mathrm{H}_{2}\right)$ dan ditumbuhkan di atas substrat gelas corning 7059 pada variasi daya 10-50 Watt, temperatur substrat $275^{\circ} \mathrm{C}$, tekanan chamber $300 \mathrm{mTorr}$, Temperatur filament $800^{\circ} \mathrm{C}$ serta laju aliran gas $\mathrm{SiH}_{4}$ sebesar 70 sccm. Dalam HWC-VHF-PECVD elemen pemanas terintegrasi pada sistem gas masukan serta peningkatan frekuensi pembangkit daya rf dari 13,56 MHz menjadi $70 \mathrm{MHz}$. Pada parameter penumbuhan tersebut diharapkan mendapatkan lapisan tipis a-Si:H yang lebih baik.
\end{abstract}

KATA KUNCI: preparasi, a-Si:H, HWC-VHF-PECVD, daya rf

\section{PENDAHULUAN}

Perkembangan pembuatan material berbasis amorf silikon (a-Si) sebagai material yang menggantikan kristal silikon (c$\mathrm{Si}$ ) ataupun poli silikon (poli-Si) dalam aplikasi beberapa bahan semikonduktor terus berkembang. Material berbasis amorf lebih unggul dalam hal biaya punumbuhan material tersebut. Tingginya temperatur penumbuhan $\left(>1000^{\circ} \mathrm{C}\right)$ menjadi salah satu penyebab mahalnya bisaya produksi [1].

Material a-Si dapat tumbuhkan dengan metode Plasma Enhanced Chemical Vapor Deposition (PECVD) dengan memanfaatkan plasma sebagai media penumbuhannya. Pada metode ini menggunakan gas Silan $\left(\mathrm{SiH}_{4}\right)$ sebagai gas sumber yang terkandung $10 \%$ dalam gas Hidrogen $\left(\mathrm{H}_{2}\right)$. Ternyata didapatkan material amorf silikon dengan kandungan hidrogen sekitar $10-20 \%$ [2], sejak saat itu material ini dikenal dengan nama amorf silikon terhidrogenisasi (a-Si:H).

Pengembangan teknik penumbuhan PECVD terus berkembang dengan pesat selain penumbuhan material amorf silikon paduan (a-SiC:H, a-SiGe:H, a-SiN:H). Perkembangan teknik itu adalah PECVD chamber ganda, VHF-PECVD, HWPECVD, HWC-PECVD dan HWC-VHF-PECVD (perkembangan di Laboratorium Fisika Material Elektronik PECVD, Departemen Fisika, Institut Teknologi Bandung) .

Secara umum metode HWC-VHF-PECVD hampir sama dengan PECVD konvensional. Hanya saja dengan

*E-MAIL: sidopekso61@yahoo.com.au meningkatkan frekuensi pembangkit daya rf dari 13,56 $\mathrm{MHz}$ menjadi $70 \mathrm{MHz}$ dan menambahkan filamen panas berupa tungsten wire pada sistem gas masukkan yang sejajar substrat, sehingga gas Silan $\left(\mathrm{SiH}_{4}\right)$ akan lebih radikal pada saat memasuki daerah elektroda karena terdisosiasi terlebih dahulu oleh elemen pemanas.

\section{PREPARASI}

Lapisan tipis a-Si:H dalam studi ini ditumbuhkan di atas gelas corning 7059 dengan menggunakan sistem HWC-VHFPECVD yang terdiri dari chamber stainless stell berdiameter 8 inci dan tinggi 12 inci tipe SS-304 dengan kevakuman sekitar -25 mTorr.

Di dalam chamber ditambahkan filamen dari kawat tungsten dengan diameter 1,2 mm diletakkan sejajar dengan substrat dan terintegrasi dengan sistem gas masukan. Kawat tungsten dibuat berbentuk spiral (lilitan) dengan diameter 5,0 $\mathrm{mm}$ dan panjang $20 \mathrm{~mm}$. Agar dapat berfungsi sebagai hotwire, filamen dipanaskan dengan menggunakan sumber arus tetap. Pengukuran suhu filamen panas ini dilakukan dengan alat tambahan yaitu Infrared Pyrometers dengan tingkat intensitas penyinaran sebesar $5 \%$ untuk material tungsten.

Untuk perbedaan konfigurasi chamber pada PECVD dan HW-Cell-PECVD dapat dilihat pada Gambar 1. Penumbuhan material a-Si:H memiliki beberapa parameter optimasi yang menentukan sifat-sifat fisis yang dihasilkan. Parameter optimasi tersebut adalah laju aliran gas Silan $\left(\mathrm{SiH}_{4}\right)$, tekanan chamber, temperatur substrat, frekuensi rf, daya rf, tegangan filament, temperatur filament, lama deposisi. Tahapan opti- 
TABEL I: Parameter penumbuhan lapisan tipis yang akan dilakukan.

\begin{tabular}{lc}
\hline \hline Parameter optimasi & HWC-VHF-PECVD \\
\hline & \\
Laju aliran gas $\mathrm{SiH}_{4}$ & $70 \mathrm{sccm}$ \\
Tekanan deposisi & $300 \mathrm{mTorr}$ \\
Temperatur substrat & $275^{\circ} \mathrm{C}$ \\
Frekuensi rf & $70 \mathrm{MHz}$ \\
Daya rf & $10-50 \mathrm{Watt}$ \\
Tegangan filament & $4,5 \mathrm{Volt}$ \\
Temperatur filament & $800^{\circ} \mathrm{C}$ \\
Lama deposisi & $5400 \mathrm{~s}$ \\
\hline \hline
\end{tabular}

masi tersebut terus dioptimalkan agar mendapatkan material a-Si:H yang berkualitas baik.

Tahapan penumbuhan terbagi menjadi 3 tahapan, yaitu:

1. Preparasi substrat.

Pada tahapan ini substrat gelas corning dibersihkan dengan alkohol $70 \%$ dan di semprotkan dengan gas Nitrogen $\left(\mathrm{N}_{2}\right)$ hingga substrat bersih hingga tidak ada lagi titik-titik debu yang menempel pada substrat.

2. Pradeposisi.

Pada tahapan ini mulai menghidupkan mesin PECVD, membersihkan chamber dan mengalirkan gas $\mathrm{N}_{2}$ agar chamber reaktor bersih dan siap dilakukan deposisi. Setelah itu memvakumkan chamber dan memanaskan substrat yang telah diletakkan di elektroda negatif dengan menggunakan Load Lock. Setelah substrat mencapai kesetabilan suhu penumbuhan, diteruskan dengan menghidupkan daya rf pada frekuensi $70 \mathrm{MHz}$, menggeset tekanan penumbuhan, dilanjutkan dengan mengalirkan gas $\mathrm{SiH}_{4}$ hingga plasma terbentuk.

3. Deposisi.
Setelah plasma terbentuk ditandai dengan adanya sinar warna ungu, dilanjutkan dengan menghidupkan filament panas dengan tegangan $4,5 \mathrm{~V}$, pengukuran temperatur filament dengan Infrared pyrometers. Setelah semua selesai deposisi siap dilakukan. Perhitungan lamanya deposisi dimulai pada saat membuka penutup substrat (shutter).

\section{KARATERISASI SAMPEL}

1. UV-Vis

Pengukuran transmitansi UV-Vis dilakukan untuk mendapatkan ketebalan lapisan, laju deposisi, koefisien absorpsi dan celah pita optik.

2. Pengukuran Konduktivitas

Sebelum pengukuran konduktivitas sampel di metalisasi dengan evaporasi dari logam alumunium sebagai kontak logam pada pengukuran konduktivitas.

\section{Ketebalan lapisan}

Ketebalan lapisan didapat dengan mengolah data hasil karakterisai UV-Vis pada transmitansi lemah dan menengah. Berikut adalah skema penentuan transmitansi lemah dan menengah.

$$
d=\frac{\lambda_{1} \lambda_{2}}{2\left(\lambda_{1} n_{2}-\lambda_{2} n_{1}\right)}
$$

dengan $\mathrm{d}=$ ketebalan lapisan, $\lambda=$ Panjang gelombang, $\mathrm{n}_{1}=$ indeks bias lapisan pada $\lambda_{1}, \mathrm{n}_{2}=$ indeks bias lapisan pada $\lambda_{2}$.

Pada absorpsi lemah dan menengah berlaku:

$$
n=\left[\left\{2 s\left(\frac{T M-T m}{T M T m}\right)+\frac{s^{2}+1}{2}\right\}+\left[\left\{2 s\left(\frac{T M-T m}{T M T m}\right)+\frac{s^{2}+1}{2}\right\}^{2}-s^{2}\right]^{\frac{1}{2}}\right]^{\frac{1}{2}}
$$

pada absorpsi transparan berlaku:

$$
n=\sqrt{\left(\frac{2 s}{T m}-\frac{s^{2}+1}{2}\right)+\sqrt{\left(\frac{2 s}{T m}-\frac{s^{2}+1}{2}\right)^{2}-s^{2}}}
$$

dengan $\mathrm{s}$ adalah indeks bias gelas corning $(\mathrm{s}=1,51)$.

\section{Laju deposisi}

laju deposisi adalah ketebalan lapisan persatuan waktu.

\section{Koefisien absorpsi}

Koefisien absorpsi merupakan hubungan antara transmitansi sebagai fungsi gelombang dengan ketebalan lapisan yang di ukur dengan UV-Vis. dengan $\alpha=$ koefisien absorpsi, $\mathrm{T}(\lambda)=$ transmitansi sebagai fungsi gelombang.

$$
\begin{aligned}
\alpha & =-\frac{1}{d} \ln \left(\frac{I}{I_{\circ}}\right) \\
& =-\frac{1}{d} \ln (T(\lambda))
\end{aligned}
$$

\section{Celah pita Optik}

Penentuan celah pita optik lapisan dapat ditentukan melalui spektrum transmitansi UV-Vis dengan metoda Tauc plot. Den- 


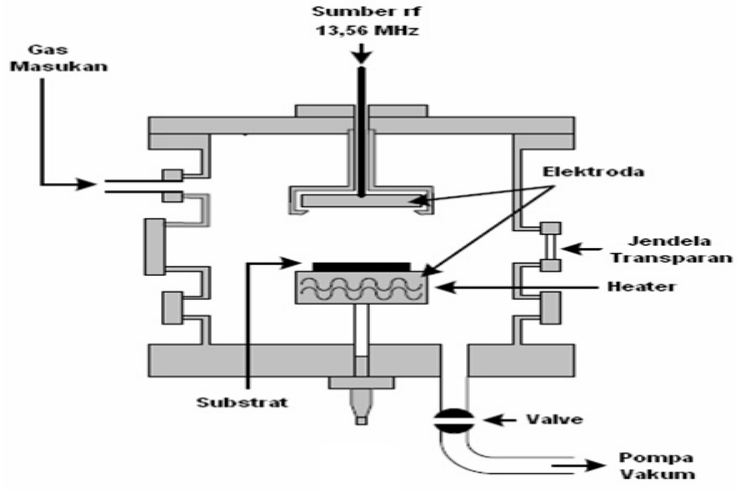

(a)

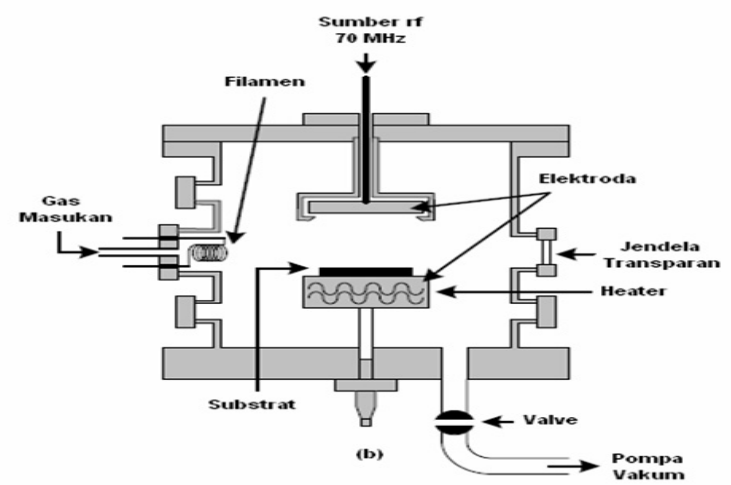

(b)

Gambar 1: Skema chamber (a) PECVD dan (b) HWC-VHF-PECVD [3]

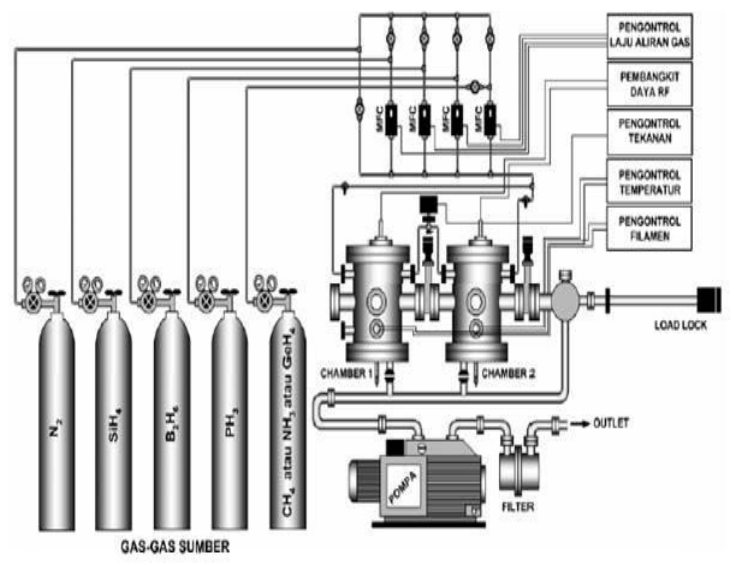

Gambar 2: Skema perpipaan pada PECVD ganda [4]

gan menarik ekstrapolasi pada daerah linier dari grafik hubungan $(\alpha \mathrm{h} \nu)^{1 / 2}$ dengan $(\mathrm{h} \nu)$ hingga mematong sumber energi.

$$
\sqrt{\alpha h \nu}=B\left(h \nu-E_{\text {opt }}\right)
$$

dengan, $\mathrm{h}=$ konstanta Plank, $\nu=$ frekuensi foton, $\mathrm{B}=$ Konstanta, $\mathrm{E}_{\text {opt }}=$ celah pita optik.

\section{Konduktivitas Listrik}

Konduktivitas listrik adalah ke-mampuan suatu bahan dalam mengalirkan arus listrik. Pada pengukuran ini menggunakan metode dua titik (koplanar) yang menggunakan fluke 8506 (amperemeter) dan keithley 617 (voltmeter). Pada pengukuran konduktivitas terang menggunakan lampu xenon 24 volt, 250 watt pada jarak penyinaran $22 \mathrm{~cm}$.

$$
\sigma=\frac{1}{\rho}=\frac{L}{R A}
$$

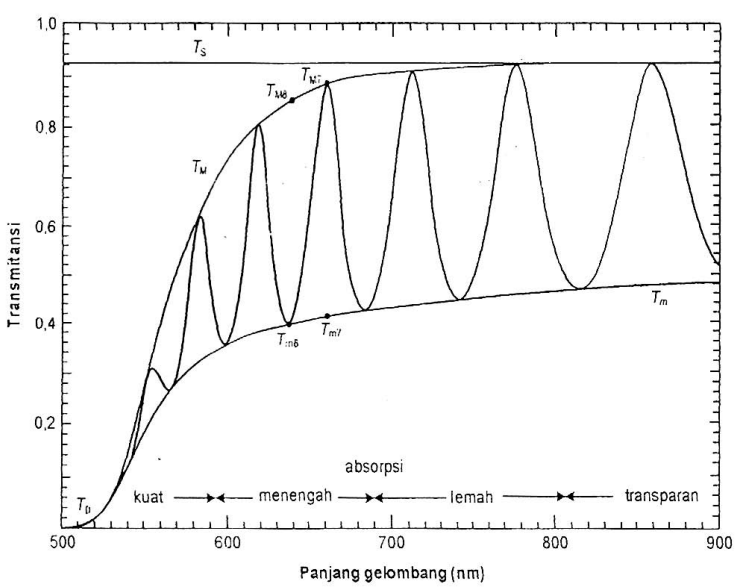

Gambar 3: Penentuan transmitansi maksimum (TM) dan transimtansi minimum (Tm) dari hasil pengukuran UV-Vis [5]

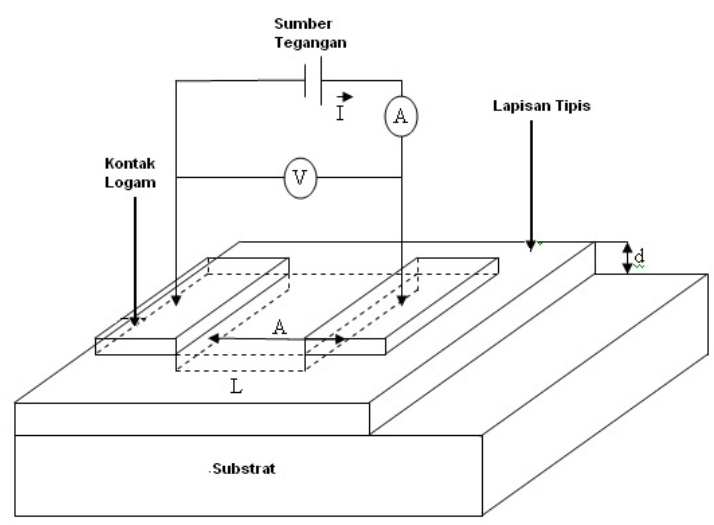

Gambar 4: Skema pengukuran konduktivitas

dengan, $\sigma=$ konduktivitas listrik, $\mathrm{R}=$ Resistansi lapisan, $\mathrm{L}$ $=$ jarak antar logam, $\mathrm{A}=$ Luas penampang yang dilewatkan arus. 


\section{SIMPULAN}

Metode HWC-VHF-PECVD adalah metode penumbuhan lapisan tipis a-Si:H yang merupakan metode pengembangan dari metode-metode sebelumnya yang mempunyai beberapa kelemahan.

Parameter optimasi menjadi indikator utama sifat-sifat fisis yang akan dihasilkan. Namum, pengembangan untuk men- dapatkan material a-Si:H tetap berlandaskan pada teknologi yang mudah, murah, efisien dan memiliki kualitas yang baik.

Tahap karakterisasi menjadi tahapan terakhir yang menunjukan siaft-sifat fisis yang dihasilkan dengan optimasi parameter penumbuhan yang dilakukan. Sifat-sifat fisis yang diperoleh menjadi tolak ukur tahapan optimasi selanjutnya agar mendapatkan kualitas lapisan tipis a-Si:H yang lebih baik lagi.
[1] Takahasi, K and Konagai, M., Amorphous Silicon Solar Cell(Nort Oxford Academic Publisher Ltd. London, 1986).

[2] Street, R. A., Hydrogenated Amorphous Silicon (Cambridge University press, Cambridge, 1991).

[3] Winata, T dan Ida, U., The Influence of Silane Gas Flow Rate on Optoelectronic Properties of c-Si:H Prepared by HWC-VHFPECVD Technique, Jurnal Sains ITB. Vol 40 A No. 2, 2008: 130137 (2008).
[4] Usman, Ida, Penumbuhan Lapisan Tipis Silikon Amorf Terhidrogensisasi dengan Teknik HWC-VHF-PECVD dan Aplikasinya Pada Devais Sel Surya, Disertasi Doktoral ITB, 2006.

[5] Swanepoel, R. et al.,Journal Applied Physics, 10, (1993)

[6] Abdullah, M dan Khairurrijal, Karakterisasi Nanomaterial. Laboratorium Sintesis Fungsional Nanomaterial ITB. Jurnal Nanosains \& Nanoteknologi. Vol 2 No. 1 Februari (2009). 